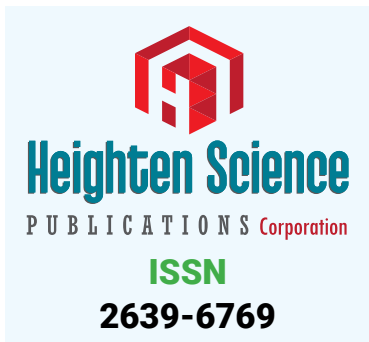

*Address for Correspondence: Marco P Soares dos Santos, Department of Mechancial Engineering, University of Aveiro, Campus Universitário de Santiago 3810-193 Aveiro, Portugal, Email: marco.santos@ua.pt

Submitted: 26 December 2017

Approved: 02 January 2018

Published: 03 January 2018

Copyright: @ 2018 Soares dos Santos MP This is an open access article distributed under the Creative Commons Attribution License, which permits unrestricted use, distribution, and reproduction in any medium, provided the original work is properly cited

Check for updates
Opinion

\section{What can Mathematics say about unsolved problems in Medicine?}

\author{
Marco P Soares dos Santos* \\ Department of Mechancial Engineering, University of Aveiro, Campus Universitário de Santiago \\ 3810-193 Aveiro, Portugal \\ Centre for Mechanical Technology and Automation (TEMA), University of Aveiro, Campus \\ Universitário de Santiago 3810-193 Aveiro, Portugal
}

Nobody doubts that mathematics plays a crucial role in medical achievements. It is certain that is being mainly used in statistics and physics for biomedical problems [1]. For sure that we have already heard about how mathematics can improve the anticancer arsenal [2]. Quantitative genetics have triggered a giant potential in medical care [3,4]. And mathematical algorithms, provided by artificial intelligence, continuously boost new therapeutic paradigms $[5,6]$. Nonetheless, one cannot ignore the ability of mathematics for analyzing ideas. One can see that when Soares dos Santos and colleagues [7] wondered what mathematics is able to say about how to optimize the performance of implantable medical devices, they wondered about the optimality of their research projects in the first place. What mathematics says about how to design "optimal" devices? It says that current devices are not able to ensure such performance. Will new or improved surgical techniques solve device failures? Mathematics also says «no». Will new or improved materials solve device failures? Mathematics says «it is possible, but it will be harder». Harder than what? Mathematics says: «Harder than instrumented active devices. Medical devices can perform optimal performances if they are active, i.e., if they are able to monitor their own state and the physiological states of the tissues surrounding the device, and if they are able to apply therapeutic actuations to such tissues so that the failure state is conducted to a without-failure state» [7-11]. And mathematics also says that this analysis can be applied to the overall implantable medical devices [7]. One cannot deny that mathematics is a powerful tool to identify what are the key challenges that must be addressed for unsolved problems in medicine. Thanks to mathematics, the universe of concepts is not apart from the clinical practice. However, medical research is being conducted by considering the paradoxicality of mathematics in medicine [1] as an assumption-the first challenge must be to question mathematics about the real accomplishments that our research projects can achieve.

\section{References}

1. T Lefèvre, E Stindel, S Ansart, C Roux. Mathematics in medicine: beyond iatromathematics. Lancet. 2014; 383: 513. Ref.: https://goo.gl/c4U5cc

2. E Dolgin. The mathematician versus the malignancy. Nature Medicine. 2014; 20: 460-46. Ref.: https://goo.gl/5M6reo

3. Lars Thielecke, Tim Aranyossy, Andreas Dahl, Rajiv Tiwari, Ingo Roeder, et al. Limitations and challenges of genetic barcode quantification. Scientific Reports. 2017; 7: 43249. Ref.: https://goo.gl/c1Tc8f

4. Trudy FC Mackay, Eric A Stone, Julien F Ayroles. The genetics of quantitative traits: challenges and prospects. Nature Reviews Genetics. 2009; 10: 565-577. Ref.: https://goo.gl/9BBLze 
5. Pavel Hamet, Johanne Tremblay. Artificial intelligence in medicine. Metabolism Clinical and Experimental. 2017; 69: 36-40. Ref.: https://goo.gl/kBjMCz

6. Vimla L Patel, Edward H Shortliffe, Mario Stefanelli, Peter Szolovits, Michael R Berthold, et al. The coming of age of artificial intelligence in medicine. Artificial Intelligence in Medicine. 2009; 46: 5-17. Ref.: https://goo.gl/JGaXRv

7. Marco P Soares dos Santos, Jorge A Ferreira, A Ramos, José A O Simões. Active orthopaedic implants: Towards optimality. J Franklin Institute. 2015; 352: 813-834. Ref.: https://goo.gl/YXWdrf

8. Marco P Soares dos Santos, Ana Marote, T Santos, João Torrão, A Ramos, et al. New cosurface capacitive stimulators for the development of active osseointegrative implantable devices. Scientific Reports. 2016; 6: 30231. Ref.: https://goo.gl/r1S3xM

9. Marco P Soares dos Santos, Jorge AF Ferreira, António Ramos, José AO Simões, Raul Morais, et al Instrumented hip joint replacements, femoral replacements and femoral fracture stabilizers. Expert Reviews of Medical Devices. 2014; 11: 617-635. Ref.: https://goo.gl/74Ynpp

10. João ND Torrão, Marco P Soares dos Santos, Jorge AF Ferreira. Instrumented knee joint implants: innovations and promising concepts. Expert Reviews of Medical Devices. 2015; 12: 571-584. Ref.: https://goo.gl/t41J3M

11. Marco P Soares dos Santos, Jorge AF Ferreira, A Ramos, José AO Simões, Raul Morais, et al. Instrumented Hip Implants: Electric Supply Systems. J Biomechanics. 2013; 46: 2561-2571. Ref.: https://goo.gl/RRiadr 